\title{
Weissella viridescens in meat products - a review
}

\author{
Marta Dušková ${ }^{1}$, Josef Kameník², Renáta Karpíšková1,3 \\ ${ }^{1}$ University of Veterinary and Pharmaceutical Sciences Brno, Faculty of Veterinary Hygiene and Ecology, \\ Department of Milk Hygiene and Technology, ${ }^{2}$ Department of Meat Hygiene and Technology, \\ Brno, Czech Republic \\ ${ }^{3}$ Veterinary Research Institute, Brno, Czech Republic \\ Received December 19, 2012 \\ Accepted May 29, 2012
}

\begin{abstract}
Although ubiquitous, bacteria of the Weissella genus are not given sufficient attention. Many members of the genus were originally classified as Leuconostoc or Lactobacillus. With the development of molecular methods, these phylogenetically closely related bacteria formed a separate group, the Weissella genus. Due to its heterofermentative metabolism, Weissella spp. may cause considerable damage particularly in the meat industry. Slime formation and greening of meat products are sensory defects for which the technologically important species Weissella viridescens is responsible. This article summarizes basic information about the influence of Weissella viridescens on meat processing.
\end{abstract}

Lactic acid bacteria, Weissella spp., spoilage, greening, thermal resistance

The negative effects of heterofermentative lactobacilli in cooked meat products were described almost 60 years ago by Niven et al. (1954). The researchers' attention was drawn to the causative agents of greening, both on the surface and in the core of products. While colour changes of the surface were caused by bacteria contaminating the product only after cooking, the greening of the product core was due to the activity of bacteria that survived elevated temperatures. In their experiment, they paid particular attention to the testing of thermal resistance of the isolated lactobacilli. While strains collected from surface colorations did not survive exposure to the temperature of $65.56^{\circ} \mathrm{C}(150 \mathrm{~F})$ for only $10-12 \mathrm{~min}$, lactobacilli in meat product cores survived that temperature for $120 \mathrm{~min}$. Under laboratory conditions, it was possible to even increase thermotolerance of certain species by successive heating.

Lörincz and Incze (1961) mentioned these heterofermentative lactic acid bacteria under the name of Lactobacillus viridescens.

Collins et al. (1993) began to be interested in a group of unknown bacteria that very closely resembled leuconostocs (the so-called Leuconostoc-like microorganisms) isolated from fermented Greek salami. Based on the results of sequential analysis of the genes 16S rRNA and other previous phylogenetic studies, a new genus Weissella was proposed. The new genus was named after the German microbiologist Norbert Weiss, whose scientific interests focused mainly on lactic acid bacteria, which also include weissellas (Collins et al. 1993). At present, we recognize 15 species of weissellas: $W$. beninensis, $W$. ceti, $W$. cibaria, $W$. confusa, $W$. fabaria, $W$. ghanensis, $W$. halotolerans, $W$. hellenica, $W$. kandleri, W. kimchii (W. cibaria), W. koreensis, W. minor, W. paramesenteroides, W. soli, $W$. thailandensis and $W$. viridescens. Weissellas belong to the family Leuconostocaceae, order Lactobacillales, class Bacilli, phylum Firmicutes and domain Bacteria (Collins et al. 1993; Tanasupawat et al. 2000; Björkroth et al. 2002; Choi et al. 2002; Lee et al. 2002; Magnusson et al. 2002; De Bruyne et al. 2008; De Bruyne et al. 2010; Padonou et al. 2010; Vela et al. 2011).

The aim of this paper was to summarize the data about the influence of Weissella viridescens on meat and meat products. 


\section{Characteristic and occurrence of Weissella spp.}

Both macroscopic and microscopic morphology of weissellas is easily interchangeable with that of other representatives of lactic acid bacteria, in particular with the leuconostocs and lactobacilli. Weissellas are Gram-positive irregular short rods with rounded ends or coccoid rods, occurring singly, in pairs or in short chains (Plate I, Fig. 1). On de Man, Rogosa and Sharpe (MRS) agar, weissellas form small transparent colonies, circular in shape of a slightly elevated profile, older cultures form a concentric structure (Plates I, II, Figs 2 and 3). These microorganisms are optionally anaerobic, and grow rapidly under microaerophilic incubation. They multiply at $15{ }^{\circ} \mathrm{C}$ but not at $45{ }^{\circ} \mathrm{C}$, with the exception of certain $W$. confusa strains. They are non-sporulating and mostly non-motile, and both oxidase and catalase negative. The $W$. paramesenteroides species is able to produce catalase at low glucose content. Under aerobic conditions, weissellas are capable of accumulating hydrogen peroxide, are unable to reduce nitrates and do not hydrolize gelatin (Niven and Evans 1957; Collins et al. 1993).

Bacteria of the genus Weissella can exist in very diverse environments. They are frequently isolated from plant material, e.g. fresh vegetables, cassava and silage (Wang and Nishinno 2008), cacao beans (De Bruyne et al. 2008), as well as from meat and meat products (Milbourne 1983; Collins et al. 1993; Han et al. 2010; Patterson et al. 2010; Han et al. 2011; Comi and Iacumin 2012; Doulgeraki et al. 2012; Kesmen et al. 2012), fish (Tanasupawat et al. 2000; Liu et al. 2009), kimchi (Choi et al. 2002; Jang et al. 2002; Lee et al. 2002), specialties from Malaysia (Björkroth et al. 2002), soil (Magnusson et al. 2002) and, in isolated cases, they can also occur in clinical material of human or animal origin. In such cases, they are of course associated with other bacteria. Weissellas are generally considered as non-pathogenic (Walter et al. 2001; Björkroth et al. 2002; Liu et al. 2009).

\section{Methods of Weissella spp. identification}

Representatives of the Weissella genus are not easy to identify by means of phenotypic methods. It is particularly problematic to differentiate between weissellas and heterofermentative lactobacilli and leuconostocs. Weissellas can be distinguished from homofermentative lactobacilli, pediococci, enterococci, lactococci and streptococci by gas production during saccharide fermentation (Collins et al. 1993). Molecular biology techniques, such as polymerase chain reaction (PCR) with genus-specific primers Weissgrp and LWrev (Schillinger et al. 2008) during which an amplicon of $1200 \mathrm{bp}$ is produced at weissellas (Plate II, Fig. 4) are more useful. To facilitate rapid identification of Weissella species, Jang et al. (2002) developed an amplified rDNA restriction analysis (ARDRA). They used restriction endonucleases $M n l \mathrm{I}, \mathrm{Mse}$ I and BceAI to cleave Weissella genusspecific product of $725 \mathrm{bp}$. For the identification of microbial diversity in Turkish dry fermented salami of the sucuk (sudžuk, soudjouk) type, Kesmen et al. (2012) used polymerase chain reaction with denaturing gradient gel electrophoresis (PCR-DGGE) for $\mathrm{V} 1$ and V3 regions of genes $16 \mathrm{~S}$ rDNA, and the interrepetitive PCR (rep-PCR) and the sequencing of genes $16 \mathrm{~S}$ rDNA and $16 \mathrm{~S}-23 \mathrm{~S}$ rDNA of intergenic regions.

\section{Weissella viridescens in meat products}

Because of their heterofermentative metabolism, weissellas may also be involved in food spoilage. They ferment glucose to DL lactic acid, with the exception of $W$. paramesenteroides and $W$. hellenica that produce $\mathrm{D}(-)$-lactic acid (Collins et al. 1993).

The most important species in the meat processing industry is $W$. viridescens (formerly Lactobacillus viridescens), which may be involved in meat product spoilage. $W$. viridescens 
ferments glucose, mannose, fructose, maltose, sometimes saccharose, and rarely also mannitol (Niven and Evans 1957).

$W$. viridescens may be the cause of slime formation or the greening of meat. Slime formation begins with individual colonies appearing on wet surface, to form a continuous layer of greenish slime later on. The underlying cause of the greening of meat products is the formation of hydrogen peroxide, which oxidizes nitrosomyochromogen, the colour pigment of meat products. Green discolouration of packaged meat products (sausages, smoked meat, vacuum-packaged meat) develops when the product is exposed to oxygen. Weissella is known to have been the cause of core greening of smoked pork loin and sausages with a lower redox potential which allowed for $\mathrm{H}_{2} \mathrm{O}_{2}$ accumulation (Marsden et al. 2009).

Many studies investigated the capability of weissellas to survive heat treatment, and the possible increase in their thermal resistance after repeated exposure to thermal shock. $W$. viridescens has been isolated from products after heating at $65{ }^{\circ} \mathrm{C}$ for $30 \mathrm{~min}$, or at $50{ }^{\circ} \mathrm{C}$ for $175 \mathrm{~min}$. It has also been detected in brine at a $10-14 \%$ concentration (Lörincz and Incze 1961). Thermoresistance of $W$. viridescens was studied also by Vrchlabský and Leistner (1971). They quote a literary reference on the strain's ability to survive in liver pâté at $95{ }^{\circ} \mathrm{C}$ for $10 \mathrm{~min}$. Under laboratory conditions, they demonstrated the protective effect of $\mathrm{NaCl}$ at concentrations in the $1.4-3.4 \%$ range on $W$. viridescens survival during cooking. Products with $\mathrm{a}_{\mathrm{w}}$ in the $0.985-0.975$ range thus offer better conditions for the survival of these bacteria at elevated temperatures.

$\mathrm{D}_{60}$ values of a majority of lactic acid bacteria are around $0.25-0.66 \mathrm{~min}$ (Franz and von Holy 1996). When Milbourne (1983) tested $W$. viridescens for survival in heated MRS broth, the $\mathrm{D}$ values that he obtained were $23.5 \min \left(\mathrm{D}_{65}\right), 12 \min \left(\mathrm{D}_{75}\right)$ and $9.5 \min \left(\mathrm{D}_{80}\right)$. However, after the weissellas had been exposed to a succession of thermal shocks, they were able to withstand the temperature of $65^{\circ} \mathrm{C}$ for $140 \mathrm{~min}$. If the Weissella can adapt itself to withstand high temperatures in the laboratory, it can do the same in processing facilities, which poses an increased risk of meat product spoilage by thermoresistant Weissella strains. $\mathrm{D}_{65}$ values obtained from survival tests of these strains in sliced ham were higher than those obtained from tests with cultivation media. Peirson et al. (2003) also obtained higher $\mathrm{D}$ values from cooked sausage test $\left(\mathrm{D}_{60}=14.7 \mathrm{~min}\right)$, weissellas in ATP broth were sensitive to heat.

Comi and Iacumin (2012) investigated spoilage in cooked hams where cavities in the muscle of hams were caused by the growth of Weissella viridescens and the $\mathrm{CO}_{2}$ produced by the fermentation of carbohydrates added to the brine which was used for the production of the hams. Spoiled hams had a slight vinegar off-flavour because weissellas produce acetic acid during fermentation. The same authors also investigated physiological properties of $W$. viridescens isolates and studied weissellas growth in 6 and $8 \% \mathrm{NaCl}$. The $6 \% \mathrm{NaCl}$ environment had no effect on the growth of weissellas, and $80 \%$ of strains grew even in $8 \% \mathrm{NaCl}$. Comi and Iacumin (2012) also found that Weissella viridescens was able to grow at refrigeration temperatures with generation times at $8{ }^{\circ} \mathrm{C}, 6{ }^{\circ} \mathrm{C}$ and $4{ }^{\circ} \mathrm{C}$ being 5, 12 and $20 \mathrm{~h}$, respectively.

Among microbial cultures involved in ham spoilage, Weissella viridescens is the most resistant against high-pressure processing of hams. It can withstand pressures of 400 to $600 \mathrm{MPa}$ at $22{ }^{\circ} \mathrm{C}$ for $10 \mathrm{~min}$. W. minor was also able to survive under those conditions, whereas $W$. paramesenteroides was not (Han et al. 2010; Han et al. 2011).

\section{Antimicrobial activity of $\boldsymbol{W}$. viridescens}

Patterson et al. (2010) demonstrated antimicrobial activity in $W$. viridescens strains against a broad range of microorganisms. This property could in the future be used to 
enhance microbiological safety of foods. The problem is, however, that not all of the tested strains demonstrated the inhibitory action against Listeria monocytogenes, Clostridium botulinum, E. coli and Salmonella spp.

In conclusion, although weissellas may cause significant financial losses particularly in the meat processing industry, they do not belong among lactic acid bacteria that get the attention of either processors or service organisations. This opens up the area for new investigation that could help to prevent sensory defects caused by the bacterial genus of Weissella.

\section{References}

Björkroth KJ, Schillinger U, Geisen R, Weiss N, Hoste B, Holzapfel WH, Korkeala HJ, Vandamme P 2002: Taxonomic study of Weissella confusa and description of Weissella cibaria sp. nov., detected in food and clinical samples. Int J Syst Evol Micr 52: 141-148

Choi HJ, Cheigh CI, Kim SB, Lee JC, Lee DW, Choi SW, Park JM, Puyn YR 2002: Weissella kimchi sp. nov., a novel lactic acid bacterium from kimchi. Int J Syst Evol Micr 52: 507-511

Collins MD, Samelis J, Metaxopoulos J, Wallbanks S 1993: Taxonomic studies on some leuconostoc-like organisms from fermented sausages: description of a new genus Weissella for the Leuconostoc paramesenteroides group of species. J Appl Microbiol 75: 595-603

Comi G, Iacumin L 2012: Identification and process origin of bacteria responsible for cavities and volatile offflavour compounds in artisan cooked ham. Int J Food Sci Tech 47: 114-121

De Bruyne K, Camu N, De Vuyst L, Vandamme P 2010: Weissella fabaria sp. nov., from a Ghanaian cocoa fermentation. Int J Syst Evol Micr 60: 1999-2005

De Bruyne K, Camu N, Lefebre K, De Vuyst L, Vandamme P 2008: Weissella ghanensis sp. nov., isolated from a Ghanaian cocoa fermentation. Int J Syst Evol Micr 58: 2721-2725

Doulgeraki AI, Ercolini D, Villani F, Nychas GJE 2012: Spoilage microbiota associated to the storage of raw meat in different conditions. Meat Sci 157: 130-141

Franz CMAP, Von Holy A 1996: Thermotolerance of meat spoilage lactic acid bacteria and their inactivation in vacuum-packaged vienna sausages. Int J Food Microbiol 29: 59-73

Han Y, Jiang Y, Xu X, Sun X, Xu B, Zhou G 2011: Effect of high pressure treatment on microbial populations of sliced vacuum-packed cooked ham. Meat Sci 88: 682-688

Han Y, Xu X, Jiang Y, Zhou G, Sun X, Xu B 2010: Inactivation of food spoilage bacteria by high pressure processing: Evaluation with conventional media and PCR-DGGE analysis. Food Res Int 43: 1719-1724

Jang J, Kim B, Lee J, Kim J, Jeong G, Han HG 2002: Identification of Weissella species by the genus-specific amplified ribosomal DNA restriction analysis. FEMS Microbiol Lett 212: 29-34

Kesmen Z, Yetiman AE, Gulluce A, Kacmaz N, Sagdic O, Cetin B, Adiguzel A, Sahin F, Yetim H 2012: Combination of culture-dependent and culture-independent molecular methods for the determination of lactic microbiota in sucuk. Int J Food Microbiol 153: 428-435

Lee JS, Lee KC, Ahn JS, Mheen TI, Pyun YR, Park YH 2002: Weissella koreensis sp. nov., isolated from kimchi. Int J Syst Evol Micr 52: 1257-1261

Liu JY, Li AH, Ji C, Yang WM 2009: First description of novel Weissella species as an opportunistic pathogen for rainbow trout Oncorhynchus mykiss (Walbaum) in China. Vet Microbiol 136: 314-320

Lörincz F, Incze K 1961: Angaben über die Grünverfärbung von Fleisch und Fleischerzeugnissen hervorrufenden Laktobazillen. Fleischwirtschaft 13: 406-408

Magnusson J, Jonsson H, Schnürer J, Roos S 2002: Weissella soli sp. nov., a lactic acid bacterium isolated from soil. Int J Syst Evol Micr 52: 831-834

Marsden J, Ahmed-Kotrola N, Saini J, Fung DYC, Phebus R 2009: Cooked meats, poultry and their products. In: Fernandes R (Ed.): Meat products. Leatherhead Food International Ltd, UK, pp. 53-82

Milbourne K 1983: Thermal tolerance of Lactobacillus viridescens in ham. Meat Sci 9: 113-119

Niven CF Jr, Buettner LG, Evans JB 1954: Thermal tolerance studies on the heterofermentative lactobacilli that cause greening of cured meat products. Appl Microbiol 2: 26-29

Niven CF Jr, Evans JB 1957: Lactobacillus viridescens nov. spec., a heterofermentative species that produces a green discoloration of cured meat pigments. J Bacteriol 73: 758-759

Padonou SW, Schillinger U, Nielsen DS, Franz CMAP, Hansen M, Hounhouigan JD, Nago MC, Jakobsen M 2010: Weissella beninensis sp. nov., a motile lactic acid bacterium from submerged cassava fermentations, and emended description of the genus Weissella. Int J Syst Evol Micr 60: 2193-2121

Patterson MF, McKay AM, Connolly M, Linton M 2010: Effect of high pressure on the microbiological quality of cooked chicken during storage at normal and abuse refrigeration temperatures. Food Microbiol 27: 226-273

Peirson MD, Guan TY, Holley RA 2003: Thermal resistances and lactate and diacetate sensitivities of bacteria causing bologna discolouration. Int J Food Microbiol 86: 223-230

Schillinger U, Boehringer B, Wallbaum S, Caroline L, Gonfa A, Huch M, Holzapfel WH, Franz CMAP 2008: 
A genus-specific PCR method for differentiation between Leuconostoc and Weissella and its application in identification of heterofermentative lactic acid bacteria from coffee fermentation. FEMS Microbiol Lett 286: 222-226

Tanasupawat S, Shida O, Okada S, Komagata K 2000: Lactobacillus acidipiscis sp. nov. and Weissella thailandensis sp. nov., isolated from fermented fish in Thailand. Int J Syst Evol Micr 50: 1479-1485

Vela AI, Fernández A, De Quiros YB, Herraez P, Dominguez L, Fernandez-Garayzabal JF 2011: Weissella ceti sp. nov., isolated from besed whales (Mesoplodon bidens). Int J Syst Evol Micr 61: 2758-2762

Vrchlabsky J, Lesitner L 1971: Thermoresistance of lactobacilli at various a $a_{w}$-value (in German). Fleischwirtschaft 51: $1368-1370$

Walter J, Hertel C, Tannock GW, Lis CM, Munro K, Hammes WP 2001: Detection of Lactobacillus, Pediococcus, Leuconostoc and Weissella species in human faeces by using group-specific PCR primers and denaturing gradient gel electrophoresis. Appl Environ Microb 671: 2578-2585

Wang F, Nishinno N 2008: Ensiling of soybean curd residue and wet brewers grains with or without other feeds as a total mixed ration. J Dairy Sci 91: 2380-2386 
Plate I

Dušková M. et al.: Weissella ... pp. 237-241

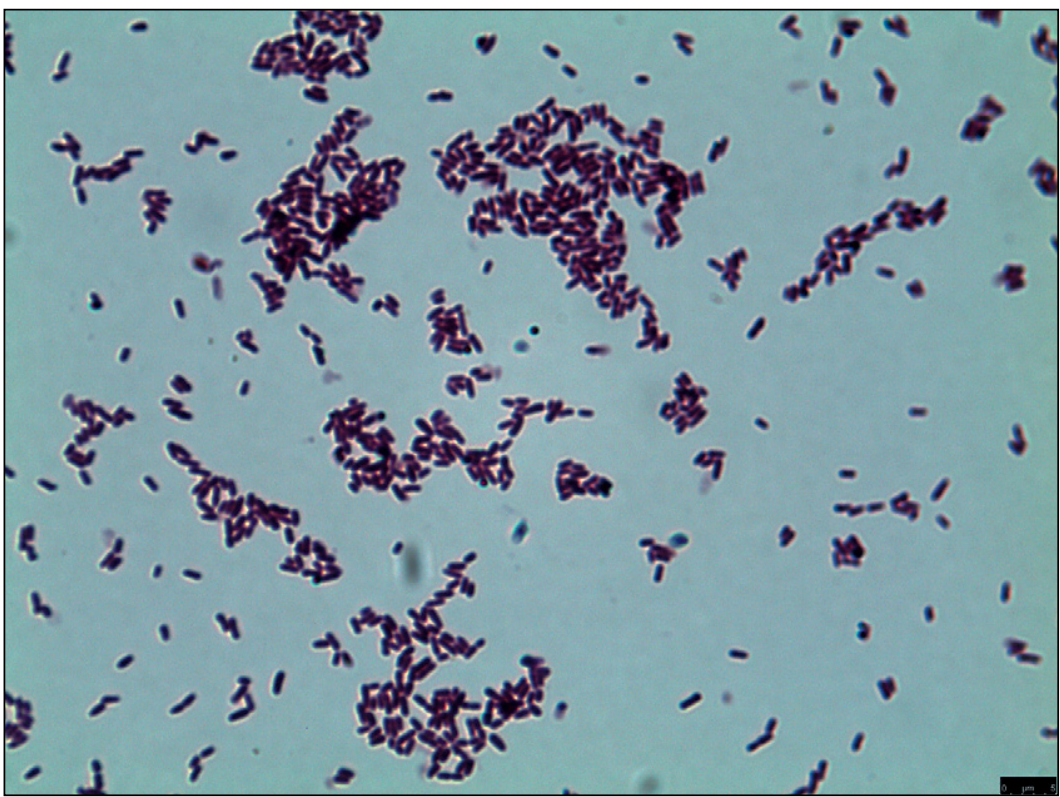

Fig. 1. Microscopy of Weissella viridescens cells stained with the Gram stain $(\times 1000$ magnification).

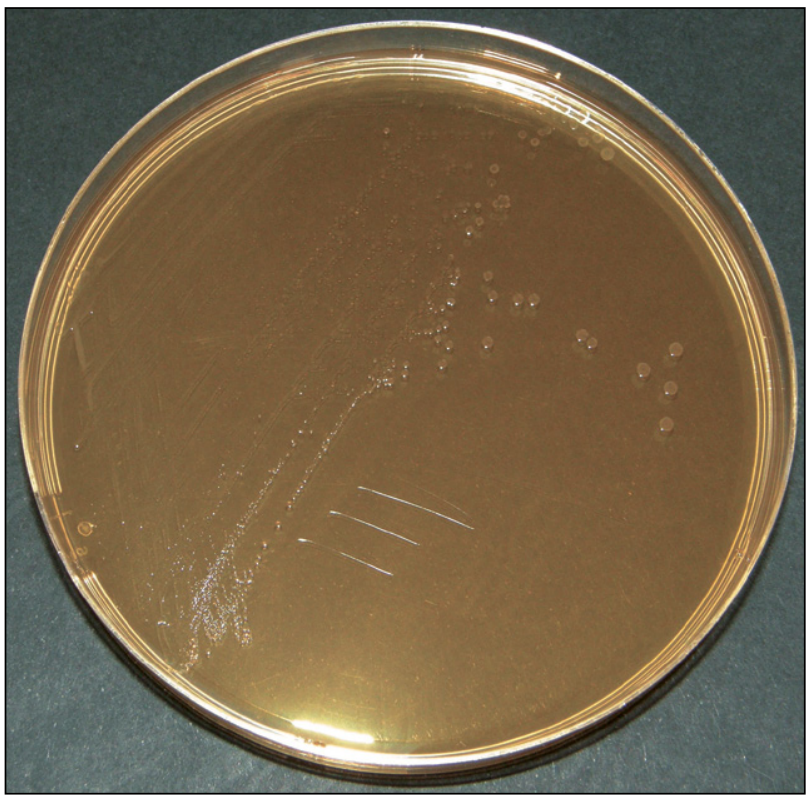

Fig. 2. Culture of Weissella viridescens isolated from dry heat-processed Vysočina salami on MRS agar (Oxoid, UK). 


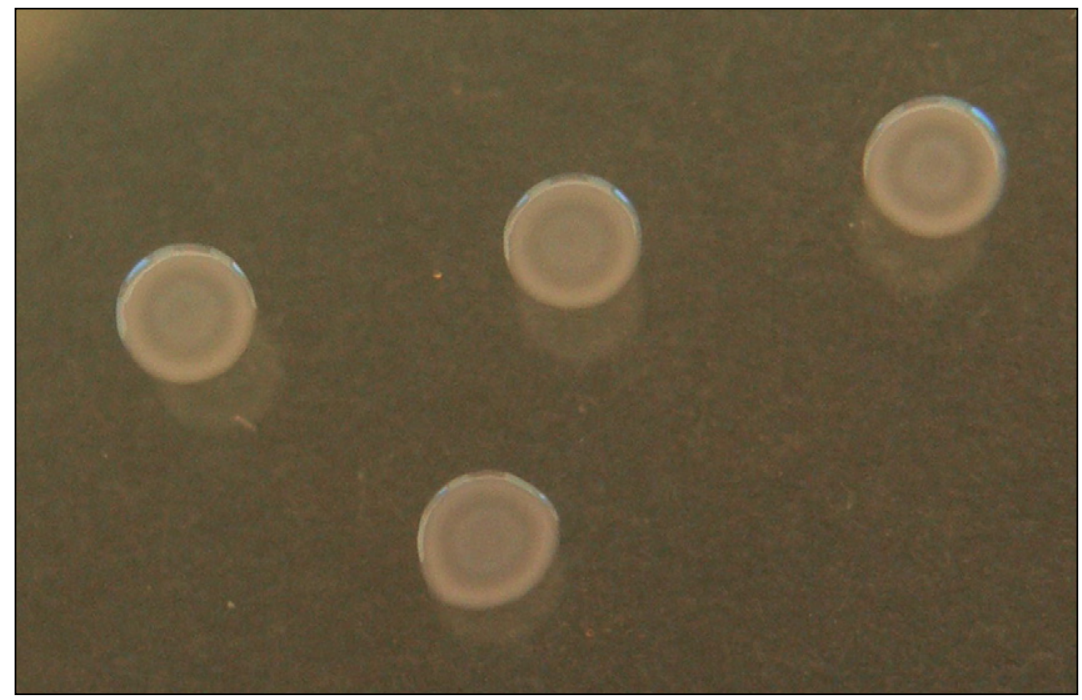

Fig. 3. A detailed view of colonies of Weissella viridescens bacteria with concentric structure on de Man, Rogosa and Sharpe agar.

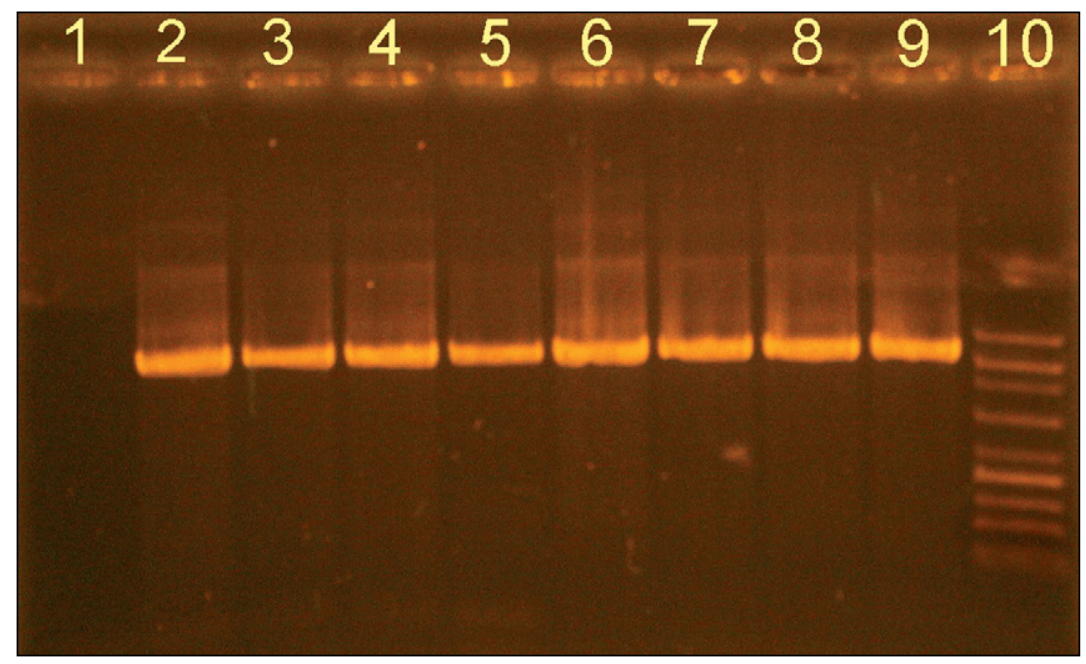

Fig. 4. Agarose gel electrophoresis of genus Weissella-specific PCR products (1200 bp). 1 negative control (PCR $\mathrm{H}_{2} \mathrm{O}$ without DNA), 2 - positive control (Weissella viridescens CCM $56^{\mathrm{T}}$ ), 3 - positive control (Weissella confusa CCM 7277), 4-9 - Weissella spp. (isolates from Vysočina salami), 10 - marker (200-1500 bp). 